\title{
Community perception of heritage values regarding a global monument in Ghana: implications for sustainable heritage management
}

\author{
Justice Mensah \\ Directorate of Academic Planning and Quality Assurance, \\ University of Cape Coast, Cape Coast, Ghana
}

Implications for sustainable heritage management

Received 21 January 2021 Revised 21 March 2021 9 May 2021 Accepted 10 May 2021

\begin{abstract}
Purpose - Scholarly discourses regarding heritage values for sustainable heritage management abound in heritage literature but appear elitist as they tend to exclude the perspectives of the people at the lower echelons of society. The study explored the values ascribed to a global heritage monument by the people living around a global heritage site in Ghana and the implications of their perceptual values for sustainable heritage management.

Design/methodology/approach - This study used the qualitative design. It was guided by Costin's heritage values, community attachment theory and values-based approach to heritage management. Data was gathered from the local people living close to the heritage site, and the staff of Museums and Monuments Board at the heritage site. Data were gathered through focus group discussions and in-depth interviews and analysed using the thematic approach and most significant stories.

Findings - The results revealed that the local people were aware of the economic, aesthetic, historic, symbolic and informational values of the heritage monument but showed little attachment to the monument. The main reasons for the low attachment were the limited opportunity for them to participate in the management of the monument, and the limited opportunity for direct economic benefits from the heritage asset.

Research limitations/implications - A comprehensive understanding of heritage monument management that reflects the perspectives and values of the local people is imperative.

Practical implications - United Nations Education, Scientific and Cultural Organisation and Ghana Museums and Monuments Board could consider a more community-inclusive heritage management framework that takes cognizance of local values and perspectives to ensure sustainable heritage management and development.

Social implications - The values and perspectives of the local community matter in heritage management. The heritage authorities need to engage more with the community people and educate them on the best practices regarding the sustainable management of World Heritage Sites.

Originality/value - This paper argues that the management of global heritage sites should not be elitist in orientation and character. It should respect the principle of community participation for inclusive development.
\end{abstract}

Keywords Global heritage monument, Heritage values, Community values and inclusion, Sustainable heritage management, Community attachment, Values-based management

Paper type Research paper

(C) Justice Mensah. Published in Journal of Humanities and Applied Social Sciences. Published by Emerald Publishing Limited. This article is published under the Creative Commons Attribution (CC BY 4.0) licence. Anyone may reproduce, distribute, translate and create derivative works of this article (for both commercial and non-commercial purposes), subject to full attribution to the original publication and authors. The full terms of this licence maybe seen at http://creativecommons.org/licences/by/4.0/legalcode

Journal of Humanities and Applied Social Sciences ol. 4 No. 4, 2022 pp. 357-375
Emerald Publishing Limited 2632-279X DOI 10.1108/JHASS-01-2021-0010 


\section{JHASS 4,4}

\section{Introduction}

Heritage, as defined by the United Nations Education, Scientific and Cultural Organisation (UNESCO, 2005) is "our legacy from the past, what we live with today, and what we pass on to future generations." The sustainable development goals (SDGs) recognise the relevance of heritage for sustainable development (SD). Hence, the goals have some targets embedded within them that focus on issues bordering on heritage management. Goal 11 of the SDGs aims to make cities and human settlements inclusive, safe, resilient and sustainable. Target 11.4 of this goal relates to strengthening efforts to protect and safeguard the value of world heritage. In heritage conservation management, a value is a set of positive characteristics or qualities that society attributes to the heritage object or site (Mason, 2002). Heritage values influence interests, attitudes, preferences, sentiments and dispositions, which are expressed in the identity and attachment to the heritage, thereby, showing its importance and the need for its proper management.

Heritage scholars and commentators (Bruku, 2015; Franquesa, 2013; Yarrow, 2017) acknowledge that managing heritage monuments requires valuing and maintaining the assets to the benefit of both the present and future generations in line with the principles and tenets of SD. Although research (Bonenberg, 2020; Forsyth, 2007; Nocca, 2017; Yarrow, 2019) has highlighted the elites' perspectives on heritage values for sustainable heritage management, they have marginalised the perspectives of the local community actors regarding the same issue. Characteristically, local communities share proximity with the heritage monuments (Bruku, 2015). Although these communities do not represent official state positions, listening to their voices could be helpful in sustainable heritage management. UNESCO (2012) admits that heritage management without community involvement is an invitation to failure. The Xi'an Declaration (ICOMOS, 2005) also observes that co-operation and engagement with local communities are essential in sustainable heritage management.

Among the prominent global heritage monuments in Africa are the historical castles. Effective management of these monuments requires the participation of all key stakeholders, including UNESCO, government and civil society, as well as the local people on whose land the heritage assets are situated. It has been found (Bruku, 2015) that while the views of stakeholders such as UNESCO and governments highly and constantly matter in the management of the global heritage monuments, the perspectives of the indigenous people are less acknowledged. Shipley and Snyder (2013) underscore the need for heritage managers to consider the value that local people place on these assets, whereas Goussous and AL-Hammadi (2017) argue that heritage attachment is linked to place identity, which is related to people's perception and the meanings that are associated with them.

In Cape Coast, Ghana is one of the global historical castles that have been designated as world heritage monuments. Naturally, it is expected that the local people would value the asset and show attachment to it by owning it and participating in its management. However, the local people appear unconcerned about the management of the asset. This deprives the asset of the critical local content in terms of its management. The purpose of this study was to explore the perceptions of the local people concerning the value they impute to the castle and the implications of these for sustainable heritage management. The study is significant as it would help in planning the form of management that would holistically protect and conserve the authenticity and integrity of the heritage site to increase the outstanding universal value (OUV) of the world heritage property (ICOMOS, 2017). The concept of OUV underpins the World Heritage Convention and all activities associated with global heritage properties. OUV means cultural and/or natural significance which is so exceptional as to 
transcend national boundaries and to be of common importance for present and future generations of all humanity (Ashworth, 1991).

\section{Literature review}

\subsection{Heritage values}

Avrami (2016) defines heritage values as the qualities attributed to tangible and intangible heritage. Heritage values, like all values, are mutable (Arlotta, 2019; Wells and Lixinski, 2016). Typically, heritage values have been categorised into historic and aesthetic. However, owing to the limitations of this categorisation, the typology has been expanded. Whereas Avrami (2016) categorises heritage values into social, spiritual, identity, research, natural and economic, Costin (1993) categorises them into symbolic, historic, informational, aesthetic and economic. Fredheim and Khalaf (2016) categorise them as associative, sensory evidentiary and functional or instrumental. Values are important in heritage management because they are an integral part of the philosophy of life. The philosophy of life includes ideas, thinking, qualities and principles by which human behaviour is guided (Wells and Lixinski, 2016). Different perspectives about heritage values are associated with diverse heritage management approaches. However, in this study, the values-based approach (VBA) is considered appropriate because of its special emphasis on stakeholder participation and inclusion in the management processes.

\subsection{Values-based approach to heritage management}

The VBA to heritage management relates to "the coordinated and structured approach to protecting the significance of a heritage asset guided by the totality of values associated with the asset" (Poulios, 2010). The theoretical approach encourages heritage management beyond academic considerations, recognising other values, voices and perspectives in the management practices. The goal is to "understand heritage management as a social and political process, as opposed to a technical problem to solve" (Mason and Avrami, 2002). Thus, VBA places people, particularly stakeholders at the centre of heritage management. The approach considers not only the maintenance of the fabric but the protection of the values imputed to the heritage. The VBA advocates equal involvement of the relevant stakeholders and their differing values in the management of heritage assets (De la Torre, 2003) With the VBA, the stakeholder groups are involved in a variety of ways: through consultation, active participation, formally established interactions or joint management schemes with the heritage authorities (Poulios, 2010) Although the coordination of, and responsibility for the overall management process may be in the hands of an overall authority, other relevant stakeholders are equitably involved in the management of the property (Demas, 2002) to ensure inclusion and sustainability.

\subsection{Community/Place attachment theory}

The theory of community/place attachment holds that people develop bonds over time from the behavioural, affective and cognitive ties between them and their socio-physical environment, making them identify with the place or community (Mihaylov and Perkins, 2014). Scannell and Gifford (2010) indicate that community or place attachment is measured using three variables: the feeling of belongingness to the place, interest in what goes on in the neighbourhood and the pleasure or displeasure that is experienced at the place. An attachment to a place or asset is a positive bond that could lead to a commitment to participate in the development of the place or asset.

Bonenberg (2020) states that for many, the heritage monument is a source of communal pride and a link to their history and cultural identity, which should be protected. Such
Implications for sustainable heritage management

359 
JHASS 4,4

people value their heritage and demonstrate attachment to it. However, for others, heritage and its management is a complex milieu requiring considerable economic and political commitment. Such people do not usually show much interest in the management of the assets. Therefore, in applying this theory in heritage management, it is imperative to promote awareness regarding the value of preserving and conserving the heritage's integrity and authenticity. This would help the community members to develop a positive bond between them and their heritage asset, thereby encouraging them to participate in its management. The response of the community to heritage management practices may occur in many forms based on their values and interactions with the heritage authorities. Their attitude toward the heritage monument depends on their attachment to it, the salience of the place to their identity, its uniqueness in serving their cultural, symbolic, historic, economic needs and on their affective bond with the cultural heritage (Mihaylov and Perkins, 2014). The response translates into action or inaction, acceptance, opposition or adaptation depending on the people's perceptions and values.

\subsection{Sustainable heritage management}

Sustainable heritage management is the process of achieving continuous improvement in the planning, preservation and conservation of heritage assets for the benefit of current and future generations (Besio, 2007; Nocca, 2017). This ensures that heritage assets facilitate the delivery of services to the public in an efficient, cost-effective way while conserving the significance of the asset for present and future generations. Datel and Dingemans (1988) carried out a survey to determine why people seek to protect and conserve heritage. The survey revealed that a knowledge of history, honour for the past and psychological benefits of continuity with the past were the most popular reasons for heritage conservation. Navrud and Ready (2002) examined the value of heritage buildings to communities and found that most authors were supportive of the value of conservation. Expounding American society's appreciation for heritage places Tyler et al. (2009), argued that heritage sites have an irreplaceable value for the community as they tell stories about who the people are and their history. However, sustainable heritage management occurs when all the relevant stakeholders are involved in the management processes. Heritage scholars (Giuliani, 2003; Jones, 2017; Yarrow, 2017) argue that this is likely to happen when the approach to the management of the asset is values-based.

\section{Study setting and method}

The study was done in three indigenous coastal settlements, namely, Abrofo Mpoano, Victoria Park and Ntsen in the Cape Coast Municipality of the Central Region of Ghana (Figure 1). It covered indigenous people living near the Cape Coast Castle (Plate 1). The study adopted the qualitative design and multi-method approach to data collection. The rationale was to provide a detailed understanding of the value that the people attached to the heritage monument and their attachment to it as well as the implications of this for sustainable management of the asset.

The study was carried out within the context of Costin's heritage values, VBA to management, and community attachment theory. Costin's heritage values were used to explore the values that the local people ascribed to the global heritage monument. Costin heritage values consider the importance of heritage within the framework of five-point values, namely, symbolic, historic, informational, aesthetic and economic as explained in Table 1. The framework was adopted because its five-pronged conceptualisation helped to understand the practical implications of heritage values for sustainable heritage management. This was supported by the community attachment theory and the VBA to 


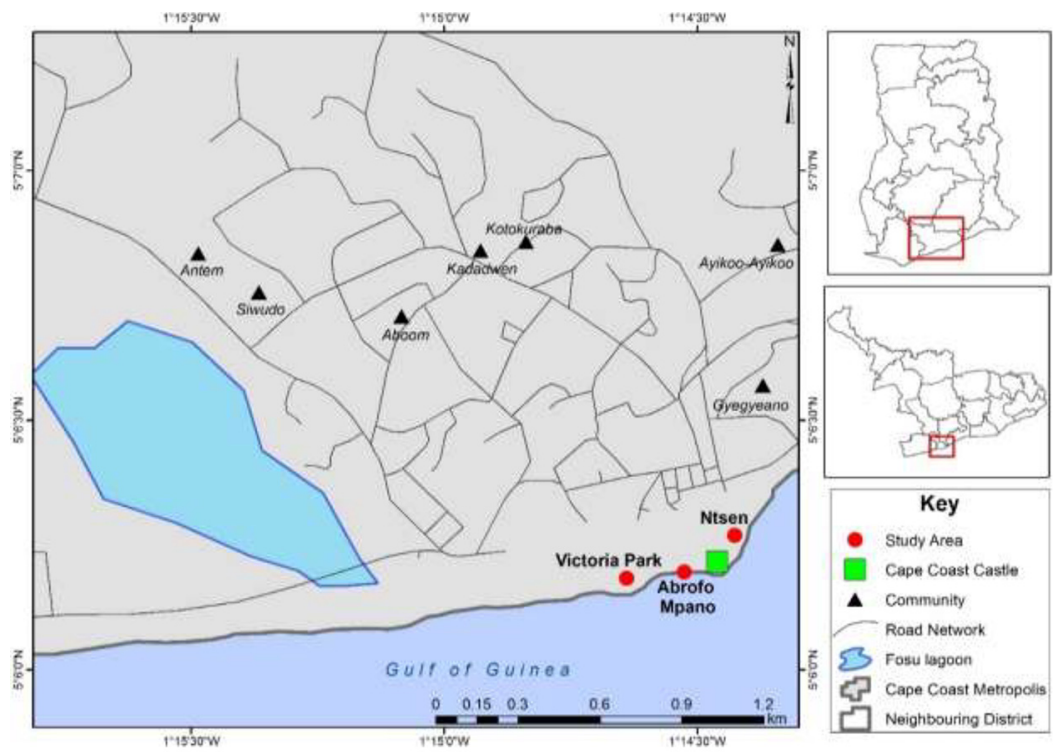

Source: Cartography Unit, University of Cape Coast, Ghana
Implications for sustainable heritage management

361

Figure 1. Map of the study area

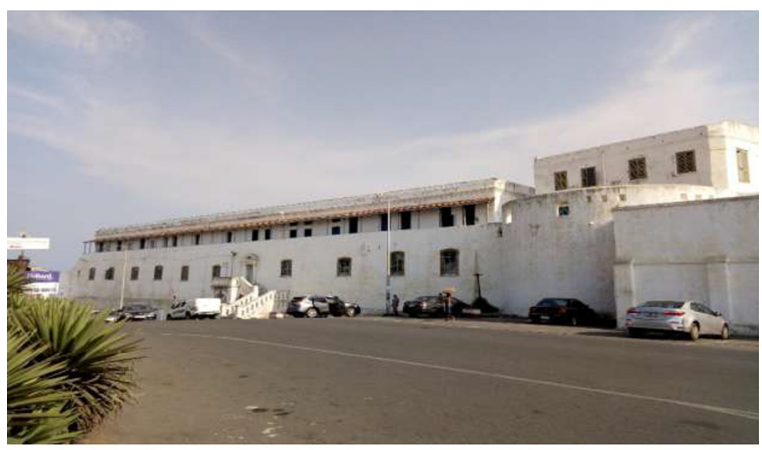

Source: Field Data, 2020

Plate 1. The Cape Coast Castle

heritage management. The approach was used to examine community involvement in the management of the heritage property, through consultation, active participation, and formally established interactions or joint management schemes with the heritage authorities. The community attachment theory was used to understand community members' bond or association with the Castle as their heritage asset and the implications of this for sustainable heritage management. The three frameworks were considered interlinked, complementary and mutually supportive in providing an understanding of heritage values for sustainable management. The theory is applicable to the study because it implies that if the local people value the asset, they will show attachment to it, and if they are attached to the asset they will value it. Either way, they will be prepared and expect to be 


\section{JHASS 4,4}

362

Table 1.

Costin's heritage values

Value Explanation

Symbolic

Historic

Informational

Aesthetic

Economic
Heritage provides awareness of and pride in cultural identity

Heritage represents eras and civilizations that have passed. Much of this heritage symbolizes a fluorescence of traditions and cultures

Heritage is essential to both public education and scholarly research, leading to new intellectual achievements

Heritage provides a beautiful and emotional experience for the viewer, leading to personal growth and development. Heritage buildings, artworks and artifacts can also serve as a creative inspiration for artists

Heritage monuments are an important focus of local, national or international tourism, thereby generating employment and revenue

Source: Adapted from Costin (1993)

involved in its management, which is good for sustainable management and inclusive development. It is also good for protecting and conserving the authenticity and integrity of the heritage asset for an enhanced OUV (ICOFORT, 2020) of the monument.

Participants were recruited using the heterogeneous purposive sampling technique. This nonprobability sampling involved the inclusion of diverse but relevant respondents. The main inclusion criteria were being a local resident, youth, opinion leader or adult who had lived in the community for at least five continuous years preceding the time of data collection. Interviews and focus group discussions were conducted for primary data. Guided by Costin's framework, the instruments covered issues on informational, economic, aesthetic, symbolic and historic values, as well as attachment to, and management of Cape Coast Castle. They also covered issues on stakeholder participation and attachment as guided by the values-based and community attachment frameworks. An observation checklist on issues relating to the geographical location and physical features of the Cape Coast Castle was also designed. The instruments were pretested at Elmina Castle, which had a similar heritage environment and conditions as the Cape Coast Castle. Results of the pretest were used to fine-tune the data collection instruments. Data were collected in October and November 2020 by the researcher and two trained research assistants, each of whom had a master's degree.

Permission of each respondent was sought before the commencement of the data collection. Literate participants signed informed consent, whereas the non-literate ones gave verbal consent after the purpose of the study had been explained to them. They were assured of confidentiality and anonymity. Data provided by the participants were audiorecorded with their permission. Data saturation was attained after collecting data from a total of 47 participants whose characteristics are provided in Table 2.

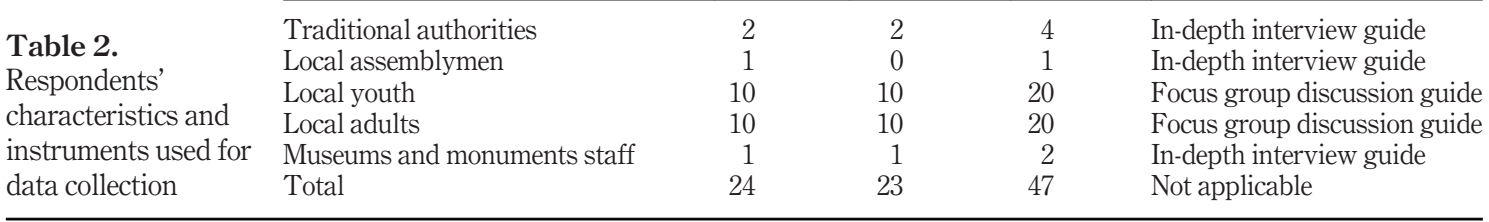


After the field data collection, the responses were transcribed and field notes typed. A thematic approach to data analysis was done. This process began with researchers' familiarization with the data after transcribing the interviews and focus group discussion (FGDs) and typing the field notes. This was done by quickly reading through the transcripts once. Then a more careful reading was done more slowly for deeper immersion into the data. Immersion in the data was important at this early stage to have a thorough understanding of the breadth and depth of the content, which provided the basis for later analysis. Then, initial codes were generated from the data. In practice, the process of coding involved going through each transcript and identifying important aspects which might form the basis of repeated patterns (themes) across the rest of the data set and labelling extracts from the interview transcripts which related to these aspects. Emerging codes were noted and where needful, were adjusted in line with interpretations of the data. Different codes were then sorted into potential themes, bringing all the relevant coded extracts from the transcripts together within the identified themes. This involved considering how different codes could be combined under broader overarching themes, clustered around the objective of the study. At any stage where disagreements occurred, they were resolved among the researchers before the next stage was embarked upon. The analysis and presentation of results were guided by Costin's heritage values, VBA to heritage management and the community attachment theory. The presentation of results was done using thick narratives and the most significant stories from the respondents.

\section{Results and discussion}

\subsection{Local people's understanding of the concept of heritage}

Woods (1984), supported by Branch and Rocchi (2015), argues that concepts are the basic units of science, therefore, concepts and science are inextricable. By the very act of identifying, naming and defining the concept, attention becomes fixed on them, and once attention is fixed on them, investigations can begin by asking relevant questions about them. Given this, questions were asked to elicit respondents' understanding of the concept of heritage. Responses elicited from the participants in respect of this are encapsulated by the following quotes:

Heritage is what our fathers, mothers, grandfathers, grandmothers' left behind for us such as buildings, clothes, utensils, fishing nets and canoes, land, sea, and festivals (Youth, Male).

Heritage is an inheritance from our forebears which we continue to use in one way or the other (Adults, Females FGD).

Heritage is our traditions and culture handed to us by our forebears (Traditional Authority, Male).

The quotes show that the local people's understanding of heritage is consistent with the formal definitions of the concept. That is, the respondents' understanding of the concept of heritage was similar to the conventional conceptions of heritage as espoused by UNESCO World Heritage Centre, and the Commonwealth Department of Sustainability, Environment, Water, Population and Communities (CDSEWPC). While the UNESCO World Heritage Centre (2005) defines heritage as "our legacy from the past, what we live with today, and what we pass on to future generations," CDSEWPC (2012) states that heritage includes stories, traditions, languages, events and assets inherited from the past. It can be concluded from the foregoing that heritage is a tangible or intangible natural or unnatural asset with significant values that can be leveraged for sustainable development. With this understanding of heritage, the participants were asked to indicate the values they placed on 
$\underset{4,4}{\text { JHASS }}$

the Castle as a heritage. Guided by Costin's theoretical model, their responses were analysed under symbolic, historic, informational, aesthetic and economic values as explained in the literature and reinforced in the methodology section of this paper.

\subsection{Symbolic value}

Costin (19993) argues that symbolic values relate to awareness of and pride in cultural identity, adding that this is important for the conservation, protection and restoration of cultural property. Therefore, the participants were asked how the Cape Coast Castle was symbolically important to them. Typical responses in this regard were as follows:

The castle is part of our cultural heritage. It is symbolic but the tourism proceeds from it go to the government so we do not benefit financially from it (Adult, Female).

We are proud of it because the whole community is identified by the castle (Youth, Male).

The fact that the castle is designated as a World heritage speaks volumes of the cultural significance and we are happy about it. For those of us who live near the castle, it is also an important landmark because wherever we go, that is what we use when we are showing people the location of our place of residence. Some of us cannot show people where we live in Cape Coast without referring to the Cape Coast Castle (Assemblyman).

It's more or less a symbol of our identity but we get close to nothing from it as local people (Traditional, Authority, Female).

From the quotes, it is clear that the local people were proud of the heritage asset and identified with it to some extent. This suggested that they had a symbolic value for the castle. The evidence supported the argument by Bonenberg (2020) that "for many, the monument is a source of communal pride as well as a major link to their cultural identity which needs to be protected." Further, not only was the evidence instructive but also consistent with ICOMOS's (2020) advocacy for the need to empower local communities to appreciate symbolic values of heritage monuments. Thus, the evidence, supported by ICOMOS's advocacy, calls for the development of effective approaches and tools for integrating communal values and local perspectives in the management of heritage assets. The approach to this should be values-based as the VBA recognises the significance of heritage not only in terms of the physical fabric but also in terms of the values ascribed by the stakeholders to the heritage asset. The local people's perception regarding the symbolic values of the castle showed how the castle was regarded by the people in terms of cultural desirability, importance and worth, which could serve as a springboard for developing community attachment to the castle. This is important because attaching meaning and identity to the heritage asset is integral to the production of a sense of place and asset. As Jokilehto (1986) observed, people's sense of place is made up of locally constituted meanings and values that they associate with the place, and this is demonstrated through their attachment to the place.

\subsection{Historic value}

Costin (1993) states that heritage represents past eras and civilizations and is of particular importance to non-literate societies as well as segments of literate societies. These civilisations are often ignored in conventional "historical" documents. Respondents were asked about the historic importance of the Castle to them. Several responses emerged from this investigation but the most significant ones were as follows: 
We heard that our great grandfathers and grandmothers were sold as slaves to go and work for the whites abroad. It certainly was terrible but that was a long go so we do not think too much about it now, although it is reprehensible and condemnable (FGD, Male Adult Local Residents).

The castle reminds us of the slave trade that happened long ago. It also reminds us that Cape Coast was once the seat of government, the capital of Ghana (Traditional Authority, Male).

But for the castles and forts, it would be very difficult for one to believe that something like the slave trade ever happened (FGD, Female Youth).

If you talk about the history of Cape Coast, the castle cannot be left out otherwise the narrative will not be complete (An Assemblyman).

The Castle is of great historic value. It reminds us of our sweet and bitter past. During the PANEFEST festival, many tourists from Black American communities in the United States visit the Castle as part of their quest to trace their ancestral roots. These are Americans of African descent who attach great importance to their history This is most significant to us as Africans in Africa and Africans in the diaspora. Interestingly, while the Africans in diaspora demonstrate attachment to the Castle, the local inhabitants do not demonstrate much attachment to it (Male, Museums and Monument Administrator, Cape Coast Castle).

The responses indicated that the local people knew a bit of the history of the castle, showing that they, at least, valued it as a heritage edifice. The community people demonstrated this value by being able to tell the history of the castle, although as expected, their historical narratives were not as succinct as the staff of the castle such as the tour guides and administrators. This could be attributed to the illiteracy of the fisherfolk as compared to the staff of the castle who were formally educated and had documents about the castle as well. The fact that the local people were able to say something which was in tandem with the documented history of the castle implied that they cared to know something about their heritage asset. It demonstrated their interest in the historical value of the monument. It could serve as the basis for community education on heritage management which could whip up more local interest in the global asset for sustainable heritage management and development.

However, unlike the Africans in the diaspora who were reported by the staff of the castle to have been showing great attachment to the heritage monument, the local people did not show much attachment to the heritage asset. This was instructive as a sentimental attachment to the heritage was essential for committing to the preservation of the authenticity and integrity of the cultural heritage for sustainable development. ICOMOS (2020) observed that cultural heritage has served as a major link to the history of the establishment and development of human settlements, nations, and even entire regions. Tyler et al. (2009) found that heritage sites had an irreplaceable value for the community as they told stories about who the people were and their history. Similarly, Yarrrow's (2018) view of heritage monuments mattered because if time was linear and unrepeating, heritage monuments and artefacts were valuable embodiments of unrepeatable pasts and unique materializations of time.

\subsection{Informational value}

Values are conscious or unconscious motivators and justifiers of actions and judgment. This means they inform actions and judgements. Costin (1993) is of the view that heritage serves an informational purpose. By this he means that heritage is essential for public education
Implications for sustainable heritage management 
JHASS 4,4

and scholarly research, leading to the opportunity for learning and intellectual advancement. Respondents were asked to indicate the informational value they placed on the castle. The following are noteworthy from their narratives in this regard:

The castle helps us to have information about our past (An Adult, Female).

We see students, tourists, teachers, and many other people who visit the castle. Obviously, they come to see the monument and learn (FGD, Male Youth).

It provides information about the slave trade. The barbaric trade should never happen again. Lecturers and other high profile people frequent the place for data and information on slavery in the past (Assemblyman).

The Castle constitutes a teaching and learning source of enormous educational importance for lecturers, students, and researchers. It's a great historical monument, a place of memory with extraordinary significance. Therefore, its monumental evocative value must be preserved and conserved for educational purposes (Tour Guide, Cape Coast Castle).

The museum and monument staff (tour guide) added that students, lecturers, researchers and journalist came to the castle all the time for information about the castle and its management. According to the informant, "these information seekers are normally interested in the history of the castle, the ignoble slave trade, and the colonial government in Ghana. The castle also provides information to international, governmental, and nongovernmental agencies such as UNESCO and ICOMOS/ICOFORT, the Ministry of Tourism and Culture in Ghana, and many more."

The evidence indicates the local people were aware of the informational value of the heritage. Although the heritage managers' report was more scholarly and informative, the local people also demonstrated appreciable knowledge of the informational value of the castle. They were able to associate the visits to the place not only with sight-seeing and leisure but also information-seeking and research. Unlike the castle manager did, the local people did not categorically mention research but implicit in their submission was research as they mentioned information about the slave trade and people coming to learn about slavery. It meant that they were aware that the castle served as a place of learning for people from all walks of life. This was consistent with the literature (Patiwael et al., 2019; Smith, 2015) that heritage assets were an important source of information for students, researchers, academics, heritage practitioners and tourists. It can be argued that the informational value helps to advance the frontiers of knowledge concerning sustainable tourism and cultural heritage management.

\subsection{Aesthetic value}

Costin's (1993) heritage values indicate that heritage monuments provide a beautiful, emotional experience for the viewer, leading to personal growth and development. Moreover, these buildings, artworks and artefacts can serve as a creative inspiration for artists. With Costin's definition of aesthetic values as the basis, the respondents were asked to indicate the aesthetic values they imputed to the castle as a heritage monument. The typical responses were:

The castle is very beautiful. One wonders how the whites were able to build such a wonderful edifice long ago when technology was not as advanced as it is today. However, it should be painted regularly to make it more beautiful and always so (Assemblyman). 
Yes, it is beautiful and nice to look at it. Some of us have taken pictures near it, using it as the background. With its wonderful architectural design and location (near the sea), you feel good when you see it (Female, Youth).

Where did they even get the building materials such as cement, block, stones at that time to build that nice monument? And did they use machines to build it or they used manpower? It's a wonderful monument but it has to be painted regularly to maintain its aesthetic appeal (Male, Youth).

It is those who have not seen it before who are amazed at it but as for me, I am used to it so it now looks ordinary to me, although I cannot deny its uniqueness and beauty (Traditional Authority, Male).

Due to its aesthetic appeal, tourists who visit the Castle always take photographs of it (Museum and Monument Administrator, Female).

It can be seen from the responses that the castle has a wonderful aesthetic value to the people. Their responses reflect the visual, therapeutic and artistic impressions of the monument. Aesthetic values are important because not only do these values promote tourism but they also could have a therapeutic effect due to their psychological impression on the viewer. Again, the aesthetic value is important as it appeals to artists and building engineers while making an impression on the general public as well as deepening the cultural significance of the castle. This resonates with the observation by Lawrence Douglas County Metropolitan Planning Office (2011) that aesthetic values, quality design and craftsmanship serve to indicate the significance of heritage monuments and the diversity of the cultures in which they were built. Similarly, Navrud and Ready (2002) examined the value of heritage monuments to communities and found that most authors were supportive of the value of their preservation, citing the aesthetic value as one of the major justifications.

4.5.1 Economic value. Costin's (1993) heritage values framework shows that archaeological sites, monuments, historic buildings and ethnographic materials in museums are an important focus of tourism in many nations. In economic terms, this generates employment and revenue. Based on Costin's perception of the economic value of heritage, the participants were asked to indicate the economic value of the Cape Coast castle to them. All the indigenous people said they were aware that a lot of money was being generated from the castle through heritage tourism. However, they indicated that they did not benefit from the revenue accruing from the castle. The quotes below amplify the voices of the respondents as far as this is concerned:

Even the President of America, Barak Obama was at the Castle a few years ago. You can imagine the number of people who came to the Cape Coast that day (Traditional Authority, Male).

People visit the castle every day. They pay for the visit but all the money goes to government coffers, therefore, we do not benefit. We hope that the money may be used for the development of Ghana but we (the indigenous residents) do not benefit directly. This is not fair (FGD with male residents).

When the tourist come over, some of them buy items from us. While they buy artifacts from the shops inside and around the castle, some also buy various food items from the local people. Some even buy fish from us. As you can see from our environment, we are primarily petty traders, fishers, and fishmongers (FGD with Female Adult Residents).

I have a daughter who has been employed as an artifact shop attendant. Although her pay is not much, she earns something from it for a living. It is better than staying at home doing nothing or engaging in unacceptable behaviours (Male Adult resident).

Implications for sustainable heritage management 
JHASS 4,4

\section{8}

They make a lot of money from the castle through tourism but we do not see what the money is used for. They say it is for the government but I believe a part will go into individual pockets. The corruption is too much in Ghana (Female Adult resident).

Local, regional, and international tourists frequent the place. Apart from the fee they pay for the tour of the interesting places of the castle, the local people make sales from such visits as some of the tourists purchase assorted items from them. This is a World Heritage Site managed by UNESCO and the government of Ghana, therefore, the revenue from its management is not meant for the local people. The revenue is meant for the maintenance of the heritage asset. In short, the economic value is the revenue that accrues from tourism which is badly needed to maintain the physical fabric of the Castle and for other development projects. The heritage asset al.so offers employment and other livelihood opportunities to the residents and other Ghanaians (Administrator, Cape Coast Castle).

The quotes show that the local people recognised the economic importance of the castle. They mentioned the revenue that went to the government as well as what they made through tourism-associated visits to the castle. However, they stated categorically that they did not benefit directly from the revenue that accrued from the castle as a tourist destination. The Museum and Monuments expert on the other hand considered the economic value from both local and national perspectives, indicating that money derived from the monuments through tourism contributed to local economic development and gross domestic product. It can be argued that the experts and local people expressed similar perspectives on the economic value of the castle. Although the museums and monuments staff were sure that the money accrued from tourism was for the maintenance of the asset and national development, most of the local people were sceptical about how the money was used, suspecting corruption and foul play in the application of the proceeds.

Although the Museums and Monuments Administrator's submission regarding the economic use of the revenue from the cultural heritage was congruent with the literature, that of the local people was at variance with it. The literature made it clear that a feature of heritage was that it provided a sustainable way to reuse existing resources that were found within the urban environment. In this way, designated historic areas played an important role in providing direct economic benefit as well as development options (Oktay Vehbi and Önal Hoskara, 2009). For a heritage property to survive, it must have a viable, economic use. This use, in turn, will ensure the maintenance of the physical fabric (Fram, 2003) of the monument, which is in tandem with the VBA's tenet that the significance of a heritage asset is not only in the fabric but also in the values ascribed by the stakeholder groups to the heritage. After all, the aim of conservation management is not simply the preservation of the fabric but the protection of the values imputed to it. The value, in this particular context, is economic.

\subsection{Management of the heritage monument}

The VBA holds that stakeholders are central to the effective management of heritage property. This is reinforced by the tenets of sustainable heritage management, which hold that all major stakeholders be part of the management of the heritage (Patiwael et al., 2019). Respondents were asked whether the local authorities were part of the management of the castle. It emerged that the local inhabitants were not part of management as can be deduced from the following quotes:

We are not part of the management, everything is centralised and is done by the government and the whites (An Assemblyman). 
The local people are not formally part of the management of the Castle. The management of the asset is in the hands of Ghana Museums and Monuments Board (GMMB), UNESCO, Government of Ghana. We consult or engage the local community people as and when the need arises. When the situation demands their engagement, we write to the Cape Coast Municipal Assembly for the needed assistance (Administrator, Cape Coast Castle).

The evidence suggests that community involvement in the management of the heritage asset was limited. Both the Assemblyman's and the Castle Administrator's reports confirmed that the local people were not directly involved in the management of the heritage asset. Although VBA (Demas, 2002) argues that the coordination of, and responsibility for the overall heritage management process is in the hands of a strong managing authority, it recognises the involvement of a whole range of the different stakeholder groups and their differing values in the management of heritage. Therefore, while there must be a lead authority among the stakeholders, the values of the community must be recognised. That is, heritage authorities need to recognise the community as a stakeholder group and prioritise their values. It should not be the case that since the heritage authorities have the right to decide how to involve the other stakeholders in the management, they should virtually marginalise the indigenous community people as stakeholders. The marginalisation was contrary to the recommendation by UNESCO/World Heritage Conservation/International Council on Monuments and Sites/ICCROM's (2019) Report on the Joint World Heritage Centre/ICOMOS/ICCROM Advisory Mission Report to the Forts and Castles in the Volta, Greater Accra, Central and Western Regions of Ghana. This report identified the limited involvement of some stakeholders in the management of heritage property in Ghana and encouraged the State Party to consider involving other role players in the management processes. Concerning challenges faced in the management of the global heritage, a Castle Administrator reported that:

We are consulted on an Adhoc basis. Our community is not represented on the GMMB. Therefore, we do not have the opportunity to articulate our views and present our perspectives on the management of the heritage asset. This is unfortunate because we feel we have a stake in the management of the asset as it is located on our land (Traditional Authority, Female).

The quote shows that the Traditional Authority expressed disappointment at the lack of representation of the community on the Management Board, which precluded the values and views of the community from being expressed. This was contrary to the spirit and letter of VBA to heritage management. As learned from the literature, values-based heritage management requires that stakeholder groups are involved in a variety of ways: through consultation, through active participation or even through formally/legally established interactions with the heritage authorities. However, unlike the cases of the World Heritage Site of Kakadu National Park in Australia (Press and Lawrence, 1995) and the World Heritage Site of Chaco Culture National Historical Park in the USA (De la Torre et al., 2003), where the stakeholders were consulted and allowed to participate in the management of the heritage assets, the communities near the Cape Coast Castle were hardly involved in the management of their heritage monument. What should be noted by the castle authorities is that although the managers of the monument may be experts and professionals, they should not downplay the role of the local people in the management of the heritage asset. The most productive approach to managing heritage assets, arguably, lies in collaborative coproduction that involves both the professionals or experts and members of the community.

An administrator at the castle reported that:

The foregoing clearly shows that the indigenous people did not participate in the management of the cultural heritage. 
JHASS 4,4

An administrator at the castle reported open defecation in the neighbourhood of the castle, which was at variance with the achievement of SDG that recognises the value of heritage assets. Goal 11 of the SDGs aims to make cities and human settlements inclusive, safe, resilient and sustainable. Target 11.4 of this goal emphasises strengthening efforts to protect and safeguard the world's cultural and natural heritage.

On a question relating to the residents' attachment to the castle, typical responses from them were as follows:

The Castle is for the government of Ghana, not us. It is the Museums and Monument Board and UNESCO that manage it. Occasionally they consult us when the need arises but in fact, we are not part of Management, therefore, our attachment to it is very low (Traditional Authority, Male).

The Castle is there for visitors/tourists, not those of us here (FGD, Adult Females).

The Castle is for the white men abroad and other visitors or tourists, We are completely detached from its management so we do not know what goes on there concerning the use of the revenue that is derived from its management (FGD, Youth Males).

It can be deduced from the responses that there was a lack of individual and communal attachment to the heritage monument. Although the monument was located in their community, real ownership was external in the sense that they felt the asset belonged to UNESCO and the Government of Ghana, not them. These owners had been managing it over the years. The lack of attachment to the heritage was contrary to the theory of community/ place attachment. The theory holds that people develop bonds over time from the behavioural, affective and cognitive ties between them and their socio-physical environment, making them identify with the place. In the case of the local people, they did not demonstrate much attachment to it because of the lack of opportunity to participate in the management of the heritage asset. The three key variables of attachment as identified by Brown and Perkins (1992); Giuliani (2003); and Scannell and Gifford (2010) in the theory of attachment, namely, feeling of belongingness, interest in what goes on in the castle and the pleasure or satisfaction derived from it were low. However, the feeling of detachment and lack of knowledge of what goes on in the castle imply that the feeling of belongingness was absent. This would negatively affect the people's commitment to helping to protect and conserve the heritage for sustainable development.

They were further asked how the castle and its associated values could be tapped or used for sustainable development. Most of the local people indicated that they would want to be involved more in the management of the Cape Coast Castle. Virtually all of them indicated that they wanted to see more transparency, accountability, inclusiveness and participation in the management of the heritage asset. Although the heritage authorities were not obliged to involve the local people in the management of the global heritage property, their own (UNESCO, ICOMOS) operational guidelines acknowledge that recognising local values in the management of the heritage asset was exceedingly useful. However, the idea of participation, transparency and accountability was laudable, the local people also had the responsibility to help curb the practice of open defecation at the beach near the castle as that was a source of concern for tourists, the government and UNESCO.

\section{Conclusion and policy recommendation}

The study examined the values of heritage monuments from the perspectives of the local people and the implications of these for sustainable heritage management and development. Costin's five-factor heritage values, community attachment theory and VBA in heritage 
management served as the theoretical frameworks for the study. It emerged that the local people fairly understood what cultural heritage meant and were somehow aware of the values of the castle as a heritage monument. The community perceptions of the property demonstrated that they ascribed historic, economic, informational, symbolic and aesthetic values to the heritage asset. This was instructive as these values are regarded in heritage management literature as key factors in the legitimization of heritage conservation management. However, the local people defecated at the beach near the heritage asset which negated the perceptual values they imputed to the asset. This was because the practice Implications for sustainable heritage management marred the aesthetic significance of the place and posed health hazards to the residents, tourists/visitors and staff at the place. Above all, it was inimical to the OUV of the global heritage property.

With their general perception showing some level of attribution of value to the heritage monument, the expectation was that the local people would demonstrate attachment to the asset. However, this was not the case as they demonstrated little attachment to it. The low level of attachment was occasioned by their reported denial of the opportunity to participate in the management of the asset. The local people saw the management of the heritage as elitist as they felt marginalised in the management processes. The reported marginalisation was incongruent with the principle of participation of all relevant stakeholders in the management of the asset. A key tenet of the VBA is that the most productive approach to effective heritage management lies in co-production, involving both professionals and members of relevant communities as stakeholders. Additionally, the marginalisation was inconsistent with UNESCO/ICOMOS position regarding heritage management, which recognises the role of the local communities in sustainable heritage management and development.

As sustainable heritage management requires the participation of key stakeholders, management practices that reflect the perspectives and values of the local community members would be helpful. There is the need, therefore, to emphasise not only the material and scientific values but also the "ascribed cultural values of the communities so that the elitist scientific values will co-exist with the communal cultural values of the local people." The heritage managers (UNESCO, the Government of Ghana, Ghana Museums and Monuments Board) should implement policies that take into account community values and perspectives to create a heritage management paradigm that ensures community inclusion for SD. The community people should also be educated on the negative effects of open defecation at the heritage site and regulated to stop the practice. UNESCO and the State Party should consider developing a stakeholder engagement and involvement plan for the heritage site, organise capacity-building programmes for the community leaders and consequently integrate them in the management of the heritage monument.

\subsection{Limitations of the study and suggestion for further studies}

As it was a qualitative study, indicator measures associated with independent variables such as community size, population density and socioeconomic class could not be compared and with variables measuring values and attachment of the indigenous community members. It is suggested that other studies be carried out using these quantitative variables.

\section{References}

Arlotta, A.I. (2019), "Locating heritage value in building material reuse", Journal of Cultural Heritage Management and Sustainable Development, Vol. 10 No. 1, available at www.emeraldinsight.com/ 2044-1266.htm 


\section{JHASS 4,4}

Avrami, E. (2016), "Making historic preservation sustainable", Journal of the American Planning Association, Vol. 82 No. 2, pp. 104-112.

Besio, M. (2007), "The management of cultural heritage: tools for conservation ad valorisation of a cultural landscape", Bellagio Forum-WHC-SiTI Training Workshop for South-Eastern Europe (1), UNESCO, Cinque terre, Italy.

Blöndal, J.R., (2003), "Accrual accounting and budgeting: key issues and recent developments", OECD Journal on Budgeting, Vol. 3 No. 1, available at: www.oecd.org/gov/budgeting/42187847.pdf (accessed 4 May 2020).

Bonenberg, W. (2020), "The role of cultural heritage in sustainable development. Values and valuation as key factors in spatial planning of rural areas", in Charytonowicz, J. and Falcão, C. (Eds), Advances in Human Factors in Architecture, Sustainable Urban Planning and Infrastructure. AHFE 2019. Advances in Intelligent Systems and Computing, Vol. 966, Springer, Cham, doi: 10.1007/978-3-030-20151-7_12

Branch, J. and Rocchi, F. (2015), “Concept development: a primer”, Philosophy of Management, Vol. 14 No. 2, pp. 111-133, doi: 10.1007/s40926-015-0011-9.

Brown, B.B. and Perkins, D.D. (1992), "Disruptions in place attachment”, in Altman, I. and Low, S. (Eds), Place Attachment, Plenum, New York, pp. 279-304.

Bruku, S. (2015), "Community engagement in historical site protection: lessons from the Elmina castle project in Ghana", Conservation and Management of Archaeological Sites, Vol. 17 No. 1, pp. 67-76, doi: 10.1179/1350503315Z.00000000094.

CDSEWPC (2012), "Annual department of sustainability, environment, water, population and communities", Annual Report, available at: www.environment.gov.au/system/files/resources/ c6a76b5d-4b84-453d-81d0-10cf6dd5e259/files/cew-annual-report-2012-13.pdf

Costin, C.L. (1993), "Legal and policy issues in the protection of cultural heritage in South Asia and the pacific", in Margaret, G.H. Mac Lean (Ed.), Cultural Heritage in Asia and the Pacific: Conservation and Policy. Proceedings of a symposium held in Honolulu, HI, pp. 8-13, September 1991 (1993).

Datel, R. and Dingemans, D. (1988), "Why places are preserved: historic districts in American and European cities”, Urban Geography, Vol. 9, pp. 37-52.

De la Torre, M., Mac Lean, M.G.H. and Myers, D. (2003), Chaco Culture National Historical Park: A Case Study, Getty Conservation Institute, Los Angeles, CA, available at: http://hdl.handle.net/10020/ gci_pubs/chaco_culture_park (accessed 7 July 2021).

Demas, M. (2002), "Planning for conservation and management of archaeological sites", in Teutonico, J.M. and Palumbo, G. (Eds), Management Planning for Archaeological Sites: An International Workshop Organised by the Getty Conservation Institute and Loyola Marymount University, May 2000, The Getty Conservation Institute, Los Angeles, pp. 27-54.

Department of Sustainability Environment Water Population and Communities (2012), "The world heritage convention", available at: www.environment.gov.au/heritage/about/world/convention. $\mathrm{html}$ (accessed 27 December 2019).

Forsyth, M. (2007), Understanding Historic Building Conservation, Blackwell Publishing, Oxford.

Fram, M. (2003), Well Preserved: The Ontario Heritage Foundation's Manual of Principles and Practice for Architectural Conservation, Boston Mills Press, Ontario.

Franquesa, J. (2013), "On keeping and selling: the political economy of heritage making in contemporary Spain”, Current Anthropology, Vol. 54 No. 3, pp. 346-369.

Fredheim, H. and Khalaf, M. (2016), "The significance of values: heritage value typologies reexamined", International Journal of Heritage Studies, Vol. 22 No. 6, pp. 466-481, doi: 10.1080/ 13527258.2016.1171247.

Giuliani, M.V. (2003), "Theory of attachment and place attachment", in Bonnes, M., Lee, T. and Bonaiuto, M. (Eds), Psychological Theories for Environmental Issues, Ashgate, Aldershot, pp. 137-170. 
Goussous, J.S. and Al-Hammadi, N.A.Q. (2017), "Place attachment assessment of a heritage place: a case study of the roman amphitheater in downtown Amman, Jordan", Frontiers of Architectural Research, Vol. 7 No. 1, pp. 1-10, doi: 10.1016/j.foar.2017.12.001.

ICOMOS (2005), Xi'an Declaration on the Conservation of Setting of Heritage Structures, Sites and Areas, ICOMOS, Paris.

ICOMOS (2017), "Introducing ICOMOS”, available at: www.icomos.org/en/about-icomos/mission-andvision/mission-and-vision (accessed 12 April 2017).

ICOMOS (2020), Final Draft ICOFORT Charter on Fortifications and Military Heritage; Guidelines for Protection, Conservation, and Interpretation. (version: July 15, 2020) ICOFORT/ICOMOS International Scientific Committee on Fortifications and Military, available at: HeritagUsers/HP/ Desktop/ARTICLES\%20New/heritage/ICOMOS\%20and \%20ICOFORT.pdf

Jokilehto, J. (1986), "A history of architectural conservation: the contribution of English, French, German and Italian thought towards an international approach to the conservation of cultural property", DPhil thesis, Institute of Advanced Architectural Studies, The University of York, York.

Jones, S. (2017), "Wrestling with the social value of heritage: problems, dilemmas, and opportunities", Journal of Community Archaeology and Heritage, Vol. 4 No. 1, pp. 21-37, doi: 10.1080/20518 196.2016.1193996.

Mason, R. (2002), “Assessing values in conservation planning: methodological issues and choices", in de la Torre, M. (Ed.), Assessing the Values of Cultural Heritage: Research Report, The Getty Conservation Institute, Los Angeles, CA, pp. 5-30.

Mason, R. and Avrami, E. (2002), "Heritage values and challenges of conservation planning", in Teutonico, J.M. and Palumbo, G. (Eds), Management Planning for Archaeological Sites: An International Workshop Organized by the Getty Conservation Institute and Loyola Marymount University, May 2000, The Getty Conservation Institute, Los Angeles, CA, pp. 13-26.

Mihaylov, N. and Perkins, D.D. (2014), "Community place attachment and its role in social capital development", in Manzo, L. and Devine-Wright, P. (Eds), Place Attachment: Advances in Theory, Methods, and Applications, Routledge, pp. 61-74.

Navrud, R. and Ready, C. (2002), Valuing Cultural Heritage: Applying Environmental Valuation Techniques to Historic Buildings, Monuments and Artifacts, Edward Elgar Publishing, Cheltenham, UK.

Nocca, F. (2017), "The role of cultural heritage in sustainable development: multidimensional indicators as decision-making tool", Sustainability, available at: MDPIheritage/Heritage\% 20SD $\% 20$ Aricle $\% 20$ in $\% 20$ Sustanbility $\% 20$ Journal.pdf

Oktay Vehbi, B. and Önal Hoskara, S. (2009), "A model for measuring the sustainability level of historic urban quarters”, European Planning Studies, Vol. 17 No. 5, pp. 715-739.

Patiwael, P.R., Groote, P. and Vanclay, F. (2019), "Improving heritage impact assessment: an analytical critique of the ICOMOS guidelines", International Journal of Heritage Studies, Vol. 25 No. 4, pp. 333-347, doi: 10.1080/13527258.2018.1477057.

Poulios, I. (2010), "Moving beyond a values-based approach to heritage conservation", Conservation and Management of Archaeological Sites - Sites, Vol. 12 No. 2, pp. 170-185, doi: 10.1179/ 175355210X12792909186539, available at: www.researchgate.net/publication/233621722

Press, T. and Lawrence, D. (1995), "Kakadu National Park: reconciling competing interests", in Press, T., Lea, D., Webb, A. and Graham, A. (Eds), Kakadu: Natural and Cultural Heritage and Management, Darwin: Australian Nature Conservation Agency and North Australia Research Unit, The Australian National University, pp. 1-14.

Scannel, L. and Gifford, R. (2010), "Defining place attachment: a tripartite organizing framework", Journal of Environmental Psychology, Vol. 30 No. 1, pp. 1-10, doi: 10.1016/j.jenvp.2009.09.006. 
JHASS 4,4

Shipley, R. and Snyder, M. (2013), "The role of heritage conservation districts in achieving community economic development goals", International Journal of Heritage Studies, Vol. 19 No. 3, pp. 304-321, doi: 10.1080/13527258.2012.660886.

Smith, A. (2015), "World heritage and outstanding universal value in the Pacific Islands", International Journal of Heritage Studies, Vol. 21 No. 2, pp. 177-190.

Tyler, N., Ligibel, T. and Tyler, I.R. (2009), Historic preservation: an introduction to its history, principles, and practice: WW Norton and Company.

UNESCO (2005), Vienna Memorandum on World Heritage and Contemporary Architecture - Managing the Historic Urban Landscape, UNESCO World Heritage Centre, Paris.

UNESCO (2012), "World heritage committee places Liverpool on list of world heritage in danger", available at: $\mathrm{http} / / /$ whc.unesco.org/en/news/890/ (accessed 21 April 2016).

UNESCO/World Heritage Conservation/International Council on Monuments and Sites/ICCROM (2019), Report on the Joint World Heritage Centre/ICOMOS/ICCROM Advisory mission to the Forts and Castles, Volta, Greater Accra, Central and Western Regions (Ghana), 28 April-2 May 2019, available at: $\mathrm{https} / / / \mathrm{whc}$.unesco.org/en/documents/176809

Wells, J.C. and Lixinski, L. (2016), "Heritage values and legal rules: identification and treatment of the historic environment via an adaptive regulatory framework (part 1)", Journal of Cultural Heritage Management and Sustainable Development, Vol. 6 No. 3, pp. 345-364.

Woods, J. (1984), "Social science concepts: a systematic analysis Giovanni Sartori Beverley Hills: Sage, 1984, pp. 455”, Canadian Journal of Political Science, Vol. 17 No. 4, pp. 841-842, doi: 10.1017/ S0008423900052720.

Yarrow, T. (2017), "Where knowledge meets: heritage expertise at the intersection of people, perspective and place", Journal of the Royal Anthropological Institute, Vol. 23 No. S1, pp. 95-109.

Yarrow, T. (2019), "How conservation matters: ethnographic explorations of historic building renovation", Journal of Material Culture, Vol. 24 No. 1, pp. 3-21, doi: 10.1177/1359183518769111.

\section{Further reading}

Brown, B., Perkins, D.D. and Brown, G. (2002), "Place attachment in a revitalizing neighbourhood: individual and block levels of analysis environment and behavior area", Family and Consumer Studies Journal of Environmental Psychology, Vol. 23 No. 2003, pp. 259-271.

de la Torre, M. and Randall, M. (200), "Introduction", in de la Torre, M. (Ed.), Assessing the Values of Cultural Heritage, The Getty Conservation Institute, Los Angeles, [Google Scholar], pp. 3-4.

Department of Environment and Heritage Protection and Queensland Heritage Council (2012), "Queensland heritage strategy: a ten-year plan", available at: www.qldheritage.org.au/heritagestrategy.html (accessed 29 December 2012).

Díaz-Andreu, M. (2017), "Heritage values and the public", Journal of Community Archaeology and Heritage, Vol. 4 No. 1, pp. 2-6, doi: 10.1080/20518196.2016.1228213.

ICOMOS Australia (1999), (1979), Charter for the Conservation of Places of Cultural Significance, (The Burra Charter), revised 1999, [Google Scholar].

Lawerance Douglas County Metropolitan Planning Office (2011), "Historic preservation plan element".

Manzo, L.C. and Perkins, D.D. (2006), "Finding common ground: the importance of place attachment to community participation and planning", Journal of Planning Literature, Vol. 20 No. 4, pp. 335-350, doi: $10.1177 / 0885412205286160$.

Orange, H. (2011), "Exploring sense of place: an ethnography of the Cornish mining world heritage site", in Schofield, J. and Szymanski, R. (Eds), Local Heritage, Global Context: Cultural Perspectives on Sense of Place, Ashgate, Farnham, pp. 99-118.

Pendlebury, J. (2013), "Conservation values, the authorised heritage discourse, and the conservationplanning assemblage", International Journal of Heritage Studies, Vol. 19 No. 7, pp. 709-727. 
Perkins, D.D. and Zimmerman, M.A. (1995), "Empowerment theory, research, and application", American Journal of Community Psychology, Vol. 23 No. 5, pp. 569-579.

Snyder, M.R. (2008), "The role of heritage conservation districts in achieving community improvement”, UWSpace, MA Thesis in Planning Waterloo, Ontario, available at: http:/hdl. handle.net/10012/3801

Implications for sustainable heritage management

Taylor, K. (2004), "Cultural heritage management: a possible role for charters and principles in Asia", International Journal of Heritage Studies, Vol. 10 No. 5, pp. 417-433.

Tonkin, S. (2012), "What is heritage? Australian Heritage Strategy", Public Consultation Paper.

UNESCO (2011), Recommendation on the Historic Urban Landscape adopted by the General Conference at its 36th session, UNESCO World Heritage Centre, Paris.

UNESCO (2015), Operational Guidelines for the Implementation of the World Heritage Convention, UNESCO World Heritage Centre, Paris.

Worthing, D. and Counsell, J. (1999), "Issues arising from computer-based recording of heritage sites", Structural Survey, Vol. 17 No. 4, pp. 200-210.

\section{Corresponding author}

Justice Mensah can be contacted at: justice44mensah@gmail.com

For instructions on how to order reprints of this article, please visit our website: 